\title{
PERSONAL BRANDING PUSTAKAWAN DI DINAS PERPUSTAKAAN DAN KEARSIPAN PROVINSI BENGKULU
}

\section{LIBRARIAN PERSONAL BRANDING IN LIBRARY AND ARCHIVES SERVICE OF BENGKULU PROVINCE}

\author{
Jenni Noka Saputra', Nurhayati Darubekti², Lailatus Sa'diyah ${ }^{3}$ \\ Program Studi Perpustakaan dan Sains Informasi, Fakultas Ilmu Sosial dan Ilmu \\ Politik, Universitas Bengkulu. Jl. WR. Supratman, Kandang Limun, Bengkulu \\ jenninokas16@gmail.com ${ }^{1}$, nurhayatidarubekti@yahoo.com ${ }^{2}$, lailasadiah@unib.ac.id ${ }^{3}$
}

\begin{abstract}
This study aims to find out how the form of personal branding at Library and Archivist Service of Bengkulu Province in order to create positive image to the librarians and library professions because nowadays librarians is still widely unknown by people and they still underestimate the professions of librarian and also seeks to increase library visitors through personal branding conducted by the librarian. This study uses qualitative descriptive method with a qualitative design obtained by interviewing and observing some informants. The data collection period in this study starts from March to June 2020. The purposive sampling method was used to obtain informants in this study by taking five informants in accordance to these considerations. Researcher uses guiding theory of personal branding formation by Peter Montoya which contained of eight aspects then compared with personal branding displayed by the informants obtained through interview and observation. The result showed that from those five informants, only one informant applied eight aspects of personal branding formation by Peter Montoya.
\end{abstract}

Key Words: Personal Branding; Imagery; Librarian; Library and Archives Service of Bengkulu Province

\begin{abstract}
ABSTRAK
Penelitian ini bertujuan untuk mengetahui bagaimana bentuk personal branding pustakawan di Dinas Perpustakaan dan Kearsipan Provinsi Bengkulu dalam upaya untuk membentuk citra yang positif terhadap profesi pustakawan dan perpustakaan dan juga berupaya untuk meningkatkan kunjungan pemustaka ke perpustakaan melalui personal branding yang dilakukan oleh pustakawan tersebut. Penelitian ini menggunakan metode deskriptif kualitatif dengan rancangan bersifat kualitatif yang diperoleh dengan wawancara dan observasi terhadap informan. Metode purposive sampling digunakan untuk memperoleh informan dalam penelitian ini dengan mengambillima informan yang sesuai dengan pertimbangan tersebut. Periode penjaringan data pada penelitian ini dimulai dari bulan Maret sampai Juni 2020. Peneliti menggunakan teori pedoman pembentukan personal branding oleh Peter Montoya yang terdapat delapan aspek kemudian membandingkan dengan personal branding yang ditampilkan oleh informan yang didapat melalui observasi dan wawancara. Hasil penelitian menunjukan dari kelima informan hanya satu informan yang menerapkan delapan aspek pembentukan personal branding dari Peter Montoya.
\end{abstract}

Kata Kunci: Personal Branding; Citra; Pustakawan; Dinas Perpustakaan dan Kearsipan Provinsi Bengkulu 


\section{PENDAHULUAN}

Masih banyak masyarakat yang belum mengenal profesi pustakawan seperti yang ditulis Murniaty (2016:1) profesi pustakawan masih belum dikenal secara meluas oleh masyarakat karena pustakawan sebagai sebuah profesi belum dapat menunjukkan jati dirinya sebagai profesi yang profesional di mata masyarakat. Saat ini masih banyak masyarakat yang belum mengetahui bahwa untuk dapat menggeluti profesi pustakawan dibutuhkan sejumlah kompetensi yang harus dipenuhi, yaitu kompetensi pendidikan, keterampilan, dan kepribadian. Semua kompetensi ini harus mengacu kepada standar yang tinggi, karena profesi pustakawan memiliki kode etik yang harus dipatuhi dan standar sertifikasi yang harus dicapai, agar pustakawannya sebagai anggota profesi dapat menjalankan tugas kepustakawanannya secara profesional sesuai standar yang telahditentukan.

Berdasarkan penelitian yang dilakukan oleh Dwi Ferra Lisia Inami dan Rizki Nurislaminingsih (2017)yang menunjukkan bahwa pustakawan memiliki spesialisasi dibidangnya seperti dibidang pustakawan ilmuan, bidang SLiMs, bidang konsultan perpustakaan, bidang kepenulisan serta bidang pengembangan TI di perpustakaan. Selanjutnya hasil temuan dari Alfian Aji (2018) juga menunjukkan bahwa dari 8 konsep membentuk personal branding ada 7 konsep yang dapat dianalisis, diantaranya spesialisasi, kepemimpinan, kepribadian, perbedaan, terlihat, kesatuan, dan nama baik. Hasil temuan dari Izzatul Muslimah (2019) menunjukkan bahwa strategi dalam membangun personal branding dihasilkan dari proses segmentasi. Segmentasi yang dilakukan adalah memetakan kondisi geografis, domografis, psikografis, behavioristic, dan sosio kultur masyarakat.

Dalam pernyataan menurut Inami \& Nurislaminingsih (2017:1) profesi pustakawan di mata masyarakat masih dipandang sebelah mata dari pada profesi-profesi lainnya seperti dokter, manajer, pengacara, guru atau profesi lainnya. Pustakawan dianggap sebagai pekerjaan yang sangat mudah bahkan seseorang tanpa latar belakang pendidikan atau pelatihan ilmu perpustakaan sekalipun dapat melakukannya. Menurut Jenifer Cram dalam Sudarsono (2006:78) yang menyatakan bahwa: "Stereotipe pustakawan selama ini dalam posisi kurang menguntungkan. Secara tidak sadar banyak pustakawan menerima begitu saja stereotipe tersebut. Sikap demikian justru semakin menguatkan stereotipe tersebut, padahal setiap profesi selalu mempunyai stereotype negatif".

Pencitraan diri atau personal branding marak dilakukan oleh tokoh-tokoh publik pada saat ini, tentunya mereka mempunyai tujuan tersendiri dalam meningkatkan personal branding mereka masing-masing, salah satunya agar menjadi populer dan terkenal. Personal branding meliputi segala aspek mulai dari untuk kepentingan politik, bisnis, fashion dan tujuan lain sesuai dengan bidang yang digeluti dari tokoh tersebut. Menurut Winoto (2016:108) personal branding adalah sebagai identitas pribadi yang mesntimuli secara tepat audience atau khalayak dalam memaknai nilai-nilai dan kualitas dari suatu lembaga yang diwakilinya pada orang tersebut.

Menurut McNally dan Speak dalam Inami \& Nurislaminingsih (2017:2) personal branding adalah persepsi atau emosi, yang dikelola atau ditangkap oleh orang lain terhadap diri kita, yang menggambarkan kualitas diri dan kecakapan untuk berhubungan dengan orang lain. Pengertian lainnya Menurut Frienhood dalam Handayani (2015:103) Personal branding adalah apa yang anda miliki sekarang yang sudah menjadi identitas anda, anda akan diidentikkan dan diasosiasikan dengan apa yang anda miliki. Dengan membangun Personal branding di masa kini, anda akan semakin naturaldimasa depan. Menurut Peter Montoya dalam Aji(2018) ada delapan konsep utama yang menjadi acuan dalam membangun suatu personal branding seseorangyaitu: 


\section{Spesialisasi (The Law of Specialization)}

Ciri khas dari sebuah Personal Brand yang hebat adalah ketepatan pada sebuah spesialisasi, terkonsentrasi hanya pada sebuah kekuatan, keahlian atau pencapaian tertentu.

\section{Kepemimpinan (The Law of Leadership)}

Masyarakat membutuhkan sosok pemimpin yang dapat memutuskan sesuatu dalam suasana penuh ketidakpastian dan memberikan suatu arahan yang jelas untuk memenuhi kebutuhan mereka. Sebuah Personal Brand yang dilengkapi dengan kekuasaan dan kredibilitas akan mampu memposisikan seseorang sebagai pemimpin.

\section{Kepribadian (The Law of Personality)}

Sebuah Personal Brand yang hebat harus didasarkan pada sosok kepribadian yang apa adanya dan hadir dengan segala ketidak sempurnaannya. Konsep ini menghapuskan beberapa tekanan yang ada pada konsep Kepemimpinan (The Law of Leadership), seseorang harus memiliki kepribadian yang baik namun tidak harus menjadi sempurna.

\section{Perbedaan (The Law of Distinctiveness)}

Sebuah Personal Brand yang efektif perlu ditampilkan dengan cara yang berbeda dengan yang lainnya. Banyak ahli pemasaran membangun suatu merek dengan konsep yang sama dengan kebanyakan merek yang ada di pasar, dengan tujuan untuk menghindari konflik. Namun hal ini justru merupakan suatu kesalahan karena merek-merek mereka akan tetap tidak dikenal di antara sekian banyak merek yang ada di pasar.

\section{Terlihat (The Law of Visibility)}

Untuk menjadi sukses, Personal Brand harus kontinuitas dan dapat dilihat secara konsisten terus-menerus, sampai Personal Brand seseorang dikenal. Maka terlihat (visibility) lebih penting dari kemampuan (ability)-nya. Untuk menjadi visible, seseorang perlu mempromosikan dirinya, memasarkan dirinya, menggunakan setiap kesempatan yang ditemui.

\section{Kesatuan (The Law of Unity)}

Kehidupan pribadi seseorang di balik Personal Brand harus sejalan dengan etika moral dan sikap yang telah ditentukan dari merek tersebut. Kehidupan pribadi selayaknya menjadi cermin dari sebuah citra yang ingin ditanamkan dalam Personal Brand. Intinya, citra yang ditampilkan harus sesuai dengan karakter sebenarnya yang tidak ditampilkan dalam personal brand sehingga tidak menimbulkan kepura-puraan dalambersikap.

\section{Keteguhan (The Law of Persistence)}

Setiap Personal Brand membutuhkan waktu untuk tumbuh, dan selama proses tersebut berjalan, adalah penting untuk selalu memperhatikan setiap tahapan dan trend. Dapat pula dimodifikasikan dengan iklan atau public relation. Seseorang harus tetap teguh pada Personal Brand awal yang telah dibentuk, tanpa pernah ragu-ragu dan berniat mengubahnya. 


\section{Nama baik (The Law of Goodwill)}

Untuk menciptakan persepsi publik seseorang harus mampu "mengarahkan" cara pandang orang lain bahwa dirinya baik. Sehingga publik merasa yakin bahwa dirinya baik dan citra yang positif ini berlangsung secara konsisten dan apa adanya tanpa dibuat-buat.

Berdasarkan beberapa pengertian di atas, sangat penting sekali sebuah personal branding dari seseorang yang mewakili lembaga atau identitasnya dalam membentuk presepsi masyarakat tentang lembaga yang diwakili olehnya, kemudian juga dapat menjadi nilai tambah orang lain terhadap dirinya sebagaimana juga dengan pustakawan dimana masyarakat masih banyak yang belum mengenal tentang profesi pustakawan, danmasih memandang rendah akan profesi tersebut.Adapun perumusan masalah yang ditentukan penulis yaitu bagaimana personal branding pustakawan di Dinas Perpustakaan dan Kearsipan Provinsi Bengkulu ? Penulis ingin mengetahui personal branding yang dilakukan pustakawan di Dinas Perpustakaan dan Kearsipan Provinsi Bengkulu dengan menggunakan delapan konsep membentuk personal branding.

\section{METODE PENELITIAN}

Penelitian ini menggunakan metode deskriptif kualitatif, dimana peneliti berusaha mendeskripsikan dan menggambarkanbagaimana personal branding pada pustakawan. Penelitian ini dilakukan di Dinas Perpustakaan dan Kearsipan Provinsi Bengkulu. Pemilihan informan menggunakan teknik purposive sampling, teknik ini digunakan dengan cara menseleksi informan berdasarkan kriteria yang telah ditentukan oleh peneliti. Hasil yang didapatkan dari pemilihan informan yaitu ada lima informan yang sesuai dengan pertimbangan. Informan penelitian ini adalah pustakawan di Perpustakaan Daerah Provinsi Bengkulu yang dipilih berdasarkan tujuan, kriteria dan pertimbangan atau pustakawan yang memiliki latar belakang pendidikan ilmu perpustakaan minimal D2, dan pustakawan yang bertugas pada layanan sirkulasi, layanan referensi dan layanan anak. Kemudian teknik yang digunakan dalam pengumpulan datanya adalah dengan cara observasi, wawancara dan dokumentasi dengan periode penjaringan datanya dimulai dari bulan Maret sampai Juni 2020.

\section{HASIL DAN PEMBAHASAN}

Penelitian dilakukan secara mendalam dengan para informan. Jumlah informan pada penelitian ini yaitu berjumlah lima orang dengan karakteristik berikut :

Tabel.1 Karakteristik Informan

\begin{tabular}{ccccc}
\hline NIP Nama & $\begin{array}{c}\text { Pangkat } \\
\text { Jabatan }\end{array}$ & Alamat & $\begin{array}{c}\text { Tempat Lahir } \\
\text { Tanggal Lahir }\end{array}$ & JK \\
\hline 19720609199903200 & Pengatur Tk.I & Kompi, Surabaya & Bukit Tinggi, & P \\
Tutik Yuniati,S.Sos. & (II/d) & & & \\
& $\begin{array}{c}\text { Pustakawan } \\
\text { Terampil }\end{array}$ & & & L 1972 \\
19641224199403100 & Pembina & Jl. Prof. Dr. Hazairin, & Kediri, & 24 Desember 1964 \\
Tony Hartanto,S.Sos. & Pustakawan & S.H No.11 & &
\end{tabular}




\begin{tabular}{|c|c|c|c|c|}
\hline $\begin{array}{c}19770407201001100 \\
\text { Efrizal, S.I.Pust. }\end{array}$ & $\begin{array}{c}\text { Penata } \\
\text { Muda(III/a) } \\
\text { Pustakawan } \\
\text { Mahir }\end{array}$ & Jl. Rawa Makmur & $\begin{array}{l}\text { Bengkulu, } \\
07 \text { April } 1977\end{array}$ & $\mathrm{~L}$ \\
\hline $\begin{array}{c}1975041219980320 \\
\text { Hasanah } \\
\text { NurfauziahPohan, } \\
\text { A.Md }\end{array}$ & $\begin{array}{c}\text { Penata }(\mathrm{III} / \mathrm{c}) \\
\text { Pustakawan } \\
\text { Penyelia }\end{array}$ & $\begin{array}{l}\text { Jl. Sumatera } 1 \text { Rt.6 } \\
\text { Sukamerindu }\end{array}$ & $\begin{array}{l}\text { Pematang Siantar, } \\
12 \text { April } 1975\end{array}$ & $\mathrm{P}$ \\
\hline $\begin{array}{c}197808182010012004 \\
\text { Azmawati, A.Md }\end{array}$ & $\begin{array}{c}\text { Penata } \\
\text { MudaTk.I } \\
\text { (III/b) } \\
\text { Pustakawan } \\
\text { Mahir }\end{array}$ & $\begin{array}{l}\text { Jl. Tut Wuri Handayani } \\
\text { Rt.5 Blok G Kel. } \\
\text { Padang Nangka Kec. } \\
\text { Singarang Pati }\end{array}$ & $\begin{array}{c}\text { Kaur, } \\
18 \text { Agustus } 1978\end{array}$ & $\mathrm{P}$ \\
\hline
\end{tabular}

Sumber data : website pustakawan.perpusnas.go.id

Berikut adalah hasil dan pembahasan dari kelima informan di atas :

\section{Spesialisasi}

Menurut Peter Montoya dalam Aji (2018-26) ciri khas dari sebuah personal branding yang hebat adalah ketepatan pada sebuah spesialisasi, terkonsentrasi hanya pada sebuah kekuatan, keahlian atau pencapaian tertentu. Peter Montoya sendiri menyebutkan ada 7 sub aspek untuk membentuk aspek spesialisasi diantaranya yaitu :kemampuan, perilaku, gaya hidup, tujuan, produk, profesi, layanan.

Spesialisasi merupakan aspek utama dalam membentuk sebuah personal brand yang mana aspek ini bisa menjadi andalan dalam membentuk sebuah brand. Seseorang yang memiliki sebuah spesialisasi yang baik akan lebih mudah untuk memperkenalkan dirinya kepada orang lain. Dalam hal ini informan menyatakan jika mereka menjadikan spesialisasi yang mereka punya sebagai modal untuk melakukan personal branding. Kelima informan lebih mengedepankan sub aspek ability atau kemampuan mereka dalam membentuk aspek spesialisasi dimana informan memanfaatkan kemampuan mereka pada bidang mereka masing-masing untuk membentuk personal branding.

Komponen spesialisasi menjadi komponen yang paling penting atau komponen paling utama dalam membentuk personal branding, pernyataan ini juga didukung oleh Inami \& Nurislaminingsih (2017:14) yang mengatakan komponen spesialisasi adalah komponen yang dapat dijadikan modal utama dalam membentuk personal branding pustakawan.

\section{Kepemimpinan}

Kepemimpinan merupakan sifat yang dimiliki oleh seseorang untuk memimpin suatu kelompok atau organisasi dalam mencapai tujuan tertentu. sebuahpersonal brand yang dilengkapi dengan kekuasaan dan kredibilitas akan mampu memosisikan seseorang sebagai pemimpin. Bagi pustakawan sifat kepemimpinan juga cukup penting dalam memutuskan sesuatu secara baik dan juga perpustakaan merupakan sebuah lembaga organisasi yang dikelola secara bersama sehingga dibutuhkannya seorangpemimpin.

Berdasarkan analisis peneliti ditinjau dari sub aspek kekuasaan dan kredibilitas dalam aspek kepemimpinan dapat dikatakan semua informan memenuhi kedua aspek tersebut jika kekuasaan yang dimaksud adalah kekuasaan berpendapat untuk memberi masukan untuk kemajuan pelayanan perpustakaan ke arah yang lebih baik. Akan tetapi jika ditinjau sebagai kekuasaan atau jabatan tinggi yang diberikan, kelima informan tidak memiliki hal tersebut maka dari itu pada sub aspek kekuasaan penerapannya hanya terbatas bagi semua informan. Pada sub aspek kedua yaitu kredibilitas semua informan mendapatkan kredibilitas atau kepercayaan baik dari pimpinan ataupun rekan kerja.

Menurut peneliti aspek kepemimpinan dalam membentuk personal branding pustakawan 
tidak terlalu berpengaruh karena kepemimpinan harus didukung dengan kekuasaan atau jabatan yang tinggi sedangkan jika ditinjau dari aspek tersebut informan tidak memilikinya. Tetapi akan jauh sangat penting jika pustakawan yang melakukan personal branding memiliki kekuasaan yang tinggi untuk mengatur atau mendukung perpustakaan dan profesi pustakawan membentuk citra bang di baik masyarakat.

\section{Kepribadian}

Kepribadian adalah cara keseluruhan seorang individu bereaksi dan berinteraksi dengan individu lain, kepribadian paling sering dideskripsikan dalam istilah sifat yang bisa diukur yang ditunjukan oleh seseorang. Sebuah personal brand yang hebat harus didasarkan pada sosok kepribadian yang apa adanya dan hadir dengan segala ketidak sempurnaannya. Artinya adalah seseorang yang melakukan personal branding harus memiliki kepribadian yang baik dan bukan hanya itu harus didasarkan pada kepribadian yang apa adanya. Pustakawan yang bertugas sebagai pelayanan masyarakat pada bidang informasi sering sekali berinteraksi kepada masyarakat sehingga pustakawan terutama dalam membentuk personal branding harus memiliki pribadi yang baik kepada pemustaka atau masyarakat sehingga masyarakat merasa nyaman untuk mencari informasi diperpustakaan.

Berdasarkan hasil wawancara menyatakan bahwa semua informan memiliki kepribadian yang ramah, baik hati, dan suka membantu pemustaka dalam memberikan informasi yang mereka butuhkan, hal ini terlihat pada saat informan memberikan pelayanan kepada pemustaka, informan berusaha memberikan pelayanan yang baik. Informan juga mengatakan tidak ada hal yang mendasari kepribadian yang mereka bentuk artinya kepribadian tersebut kepribadian alami yang dimiliki oleh informan tidak dibentuk karena ingin melakukan personal branding semata.

Menurut analisis peneliti aspek kepribadian termasuk ke dalam salah satu aspek yang penting dalam membentuk personal branding bagi seorang pustakawan, karena kepribadian yang baik dapat menjadi modal yang bagus terutama pada saat memberikan pelayanan kepada pemustaka karena pada saat itu pustakawan akan sering berinteraksi kepada pemustaka maka dari itu sangat diperlukannya kepribadian yang baik yang dimiliki oleh pustakawan agar pemustaka merasa nyaman untuk mencari informasi di perpustakaan.

\section{Perbedaan}

Sebuah produk jika ditampilkan atau dipasarkan seperti biasa atau yang umum dilakukan tidak akan banyak menarik perhatian masyarakat, akan tetapi jika produk ditampilkan dengan cara yang berbeda dan unik akan jauh lebih menarik perhatian masyarakat karena cara atau proses pemasaran dari produk tersebut berbeda dari kebanyakan produk yang lain. Hal yang sama dikatakan oleh Peter Montoya dalam Aji (2018:27) sebuah personal brand yang efektif perlu ditampilkan dengan cara yang berbeda dengan yang lainnya. Pustakawan yang melakukan personal branding dituntut untuk lebih kreatif dalam membentuk personal branding mereka agar pemustaka mudah dan cepat mengingat kepada pustakawan tersebut melalui personal branding yang dilakukanpustakawan.

Pada hasil wawancara dengan informan peneliti mendapatkan bahwa dari kelima informan hanya satu informan yang menerapkan aspek perbedaan, peneliti menganalisis aspek perbedaan dari informan tersebut yaitu terdapat dari teknik pelayanan yang dilakukan oleh informan yaitu dengan mendekatkan diri kepada pemustaka membantu secara langsung mencoba untuk berbaur dengan pemustaka, hal ini merupakan sesuatu yang sangat positif dalam upaya membentuk citra pustakawan yang baik. Informan berusaha mendatangi pemustaka yang dirasa perlu bantuan kemudian dengan melakukan pendekatan dan mencoba mencari tahu 
permasalahan yang sedang dihadapi pemustaka informan kemudian menjelaskan tahapan mencari sumber informasi di perpustakaan dari menggunakan OPAC sampai mencari bahan pustaka di rak buku dan juga memberikan saran atau rujukan kepada pemustaka jika koleksi yang dibutuhkan oleh pemustaka tidak didapatkan di Dinas Perpustakaan dan Kearsipan Provinsi Bengkulu. Informan mengaku jika kebanyakan pemustaka malu atau seganbertanyasecara langsung kepada petugas maka dari itu teknik yang dilakukan oleh informan sangat positif dan menumbuhkan image kepada pemustaka bahwa pustakawan di Dinas Perpustakaan dan Kearsipan Provinsi Bengkulu baik dan suka membantu pemustaka, dan juga hal ini juga dapat menumbuhkan loyalitas kepada pemustaka untuk tetap sering berkunjung ke perpustakaan.

Aspek perbedaan menjadi aspek yang juga sangat penting dalam tahapan membentuk personal branding menurut Peter Montoya hal ini juga didukung dengan pendapat Inami \& Nurislaminingsih (2017) yang menyatakan bahwa komponen perbedaan dianggap penting bagi seorang pustakawan untuk membedakan dengan pustakawan lainnya, sangat disayangkan pada penelitian ini peneliti hanya menemukan satu informan yang menerapkan aspek ini karena aspek perbedaan ini menjadi aspek yang utama dalam membentuk sebuah personal branding bagi pustakawan.

\section{Terlihat}

Seorang pelaku personal branding yang memiliki aspek spesialisasi yang baik aspek kepemimpinan dan aspek yang lainnya namun tidak konsisten dalam melakukan personal branding tersebut maka tujuan dari personal branding tersebut sulit dicapai, karena konsisten atau terlihat merupakan aspek yang juga penting dalam pembentukan sebuah personal branding, bahkan konsistensi lebih penting dari kemampuan dalam melakukan personal branding. Seperti yang dikatakan Peter Montoya dalam Handayani (2015:108) untuk menjadi sukses, Personal Brand harus dapat dilihat secara konsisten terus-menerus, sampai Personal Brand seseorang dikenal. Maka visibility lebih penting dari kemampuan (ability)-nya. Untuk menjadi visible, pustakawan perlu mempromosikan dirinya, memasarkan dirinya, menggunakan setiap kesempatan yang ditemui dan memiliki beberapa keberuntungan dengan berpromosi.

Pada penelitian ini peneliti mendapatkan pernyataan dari informan bahwa mereka selalu menggunakan kesempatan yang mereka temui dalam melakukan personal branding yaitu pada saat melakukan pelayanan kepada pemustaka, mereka selalu berusaha memberikan pelayanan yang baik kepada pemustaka jika menemui kesempatan tersebut, apa yang dilakukan oleh informan sudah cukup baik dimana mereka sudah berhasil dalam menerapkan aspek terlihat ini, mungkin akan lebih baik jika konsistensi mereka terus didukung dengan kreatifitas yang terus ditingkatkan dalam melakukan personal branding.

Seperti Pernyataan Peter Montoya diatas konsistensi atau terlihat menjadi aspek yang penting dalam melakukan personal branding, bahkan Peter Montoya mengatakan konsistensi lebih penting dari pada kemampuan, akan tetapi konsistensi harus selalu didukung dengan kemampuan yang baik kreatifitas dari pelaku personal branding khususnya pustakawan agar tujuan dari personal branding itu sendiri akan mudah untuk dicapai.

\section{Kesatuan}

Seorang pelaku personal branding dituntut untuk membentuk pribadi yang baik karena tentunya dalam melakukan personal branding tentu harus bersikap baik, ramah kepada target branding agar seseorang dapat dicitrakan dengan baik, namum dalam melakukan hal tersebut hendaknya pelaku personal branding harus sejalan dengan kepribadiannya sehari-hari saat tidak melakukan branding karena hal tersebut malah akan menjadi bumerang jika pelaku melakukannya dengan unsur kepura-puraan. Jadi pelaku personal branding hendaknya mebentuk pribadi yang baik dan harus sejalan dengan kehidupannya sehari-hari. Seperti yang dikatakan Peter Montoya dalam Handayani (2015:108) kehidupan pribadipustakawan dibalikpersonal brandharus sejalan 
dengan etika moral dan sikap yang telah ditentukan dari citra tersebut. Kehidupan pribadi pustakawan selayaknya menjadi cermin dari sebuah citra yang ingin ditanamkan dalam personal brand.

Peneliti mendapatkan bahwa informan dalam penelitian ini mengaku bahwa dalam membentuk kepribadian mereka yang ditampikan dalam personal branding hal tersebut tidak dibentuk secara khusus, mereka mengatakan jika pribadi yang mereka bentuk sesuai dengan kepribadian mereka sehari-harinya, hal ini sesuai dengan apa yang dikatakan dalam pernyataan Peter Montoya diatas dimana mereka dalam melakukan personal branding selalu mengedepankan ramah, baik hati, dan suka membantu pemustaka yang membutuhkan informasi di perpustakaan yang diimplementasikan kedalam layanan yang mereka berikan kepada pemustaka dan kepribadian tersebut juga tetap mereka terapkan pada saat dilingkungan masyarakat ataukesehariannya.

Menurut analisis peneliti aspek kesatuan juga menjadi aspek yang penting dalam membentuk sebuah personal branding bukan menjadi aspek yang utama akan tetapi aspek kesatuan menjadi aspek yang mendukung agar tujuan dari personal branding itu sendiri terwujud, aspek kesatuan menjadi catatan atau peringatan bagi pelaku personal branding jika membentuk sebuah brand harus sesuai atau bercermin kepada kehidupan sehari-hari mereka agar hal ini tidak menjadi bumerang bagi mereka dalam membentuk sebuahbranding.

\section{Keteguhan}

Dalam membentuk sebuah personal branding dibutuhkan waktu untuk membuat image yang baik ke masyarakat sesuai dengan tujuan dari personal branding tersebut, untuk mendapatkan hal itu pelaku personal brand harus konsisten baik dalam hal intensitas dalam melakukan branding maupun keteguhan pada personal brand awal yang sudah dibentuk. Dalam artian seseorang harus teguh pendirian dalam menetapkan personal brand-nya dan bersabar dalam membuat citra mereka baik dimata masyarakat. Seperti apa yang dikatakanPeter Montoya dalam Handayani (2015:108) Setiap Personal Brand membutuhkan waktu untuk tumbuh, dan selama proses tersebut berjalan, adalah penting untuk selalu memperhatikan setiap tahapan dan trend. Dapat pula dimodifikasikan dengan menggunakan sarana promosi Perpustakaan, dengan tujuan agar Pustakawan dapat dikenal. Pustakawan harus tetap teguh pada Personal Brand awal yang telah dibentuk, tanpa pernah ragu-ragu dan berniat merubahnya.

Pada aspek ini peneliti menemukan bahwa semua informan menyatakan bahwa mereka teguh dengan personal branding yang mereka bentuk dari awal, dan juga mereka mengungkapkan selain teguh pada branding yang dibentuk mereka juga mengatakan memperbaiki dan meningkatkan apa yang telah mereka lakukan untuk mencapai tujuan dari personal branding itu sendiri. Informan dicitrakan sebagai seorang yang ramah, baik hati, dan suka membantu pemustaka yang membutuhkan informasi yang mereka butuhkan, mereka menyatakan akan tetap menjaga hal tersebut dan mencoba memperbaiki apa yang masih menjadi kekurangan dan berusaha untuk mengikuti perkembangan zaman.

Menurut analisis peneliti aspek keteguhan merupakan aspek pendukung yang membantu dalam membentuk sebuah personal branding walaupun bukan aspek utama namun aspek keteguhan juga merupakan aspek yang penting, dimana pelaku personal branding dituntut untuk teguh pada pendiriannya tentang personal branding yang mereka bentuk, seperti yang dikatakan
oleh
Peter
Montoya
dalam
Handayani
(2015). 


\section{Nama Baik}

Setelah membentuk sebuah personal brand juga penting untuk tetap mempertahankan nama baik yang sudah dibentuk dari strategi yang sudah dilakuakan dalam personal branding. Nama baik merupakan hal yang penting dalam membentuk sebuah personal branding seseorang yang dipresepsikan dengan baik akan lebih mudah untuk melakukan personal branding kepada masyarakat. Menurut Peter Montoya dalam Aji (2018) pelaku personal branding harus mampu mengarahkan publik kepada presepsi yang baik terhadap dirinya agar personal branding yang dibentuk seseorang dapat diterima oleh masyarakat. Tidak kalah penting dari membentuk nama baik yaitu pelaku personal branding harus mampu mempertahankan nama baik yang sudah didapatkan dari masyarakat, pelaku personal branding harus tetap menjaga nama baik yang sudah didapatkan, sehingga jika kedua hal ini telah dilakukan maka tujuan dari personal branding tersebut akan mudah untuk dicapai.

Dari personal branding yang sudah diupayakan oleh informan mereka selalu berusaha untuk membuat citra yang baik untuk profesi pustakawan dan instansi atau perpustakaan yang mereka bawa yaitu Dinas Perpustakaan dan Kearsipan Provinsi Bengkulu. Mereka selalu berupaya untuk membentuk citra yang ramah, baik hati, dan suka membantu pemustaka melalui personal branding yang mereka lakukan yang diimplementasikan kedalam layanan yang mereka berikan kepada pemustaka. Informan juga mengaku selain itu mereka juga berusaha menjaga nama baik mereka dan berusaha untuk memperbaiki kekurangan dari yang sudah merekalakukan.

Menurut analisis peneliti aspek nama baik juga merupakan salah satu aspek pendukung dalam membentuk personal branding dari Peter Montoya, aspek nama baik menjadi aspek terakhir yang menjadi penutup dari tahapan-tahapan atau aspek-aspek sebelumnya, dimana aspek nama baik berupaya untuk membuat citra yang baik kepada masyarakat kemudian mempertahankan nama baik tersebut. Jika pelaku personal branding sudah dicitrakan dengan presepsi yang baik hal ini akan sangat mendukung personal branding seseorang untuk mecapai tujuannya. Dalam perpustakaan aspek ini juga sudah terbentuk melalui pustakawan yang melakukan personal branding maka dampaknya akan sangat baik untuk perpustakaan seperti baiknya presepsi masyarakat tentang perpustakaan dapat menumbuhkan loyalitas pemustaka sehingga pemustaka akan lebih sering mencari informasi di perpustakaan dan dapat menumbuhkan minat kunjung masyarakat keperpustakaan.

Berdasarkan analisa peneliti dari delapan aspek membentuk personal branding menurut Peter Montoya dalam Aji (2018) hanya ada satu informan yang menerapkan seluruh aspek tersebut. Menurut analisa peneliti mengapa hanya satu informan yang menerapkan kedelapan aspek tersebut peneliti menemukan bahwa dilihat dari pendidikan ilmu perpustakaan yang ditempuh dari semua informan bahwa hanya informan Tony Hartanto yang menerapkan seluruh aspek personal branding yang menempuh pendidikan ilmu perpustakaan di pulau Jawa yaitu UNPAD (Universitas Padjajaran) sedangkan keempat informan lain mendapatkan ilmu perpustakaan di USU (Universitas Sumatera Utara) dua dianataranya di UT (Universitas terbuka) dan satu lagi di UNIB (Universitas Bengkulu) hal ini menurut peneliti menjadi salah satu faktor mengapa hanya informan Tony Hartanto yang menerapkan semua aspek personal branding menurut Peter Montoya dalam Aji (2018). 


\section{KESIMPULAN}

Berdasarkan hasil penelitian yang telah dilakukan mengenai personal branding pustakawan di Dinas Perpustakaan dan Kearsipan Provinsi Bengkulu yang ditinjau dari konsep personal branding dari Peter Montoya dalam Aji (2018:26-28) maka peneliti menarik kesimpulan sebagai berikut:

Berdasarkan hasil analisis peneliti dapat ditarik kesimpulan bahwa aspek yang paling utama dalam membentuk personal branding bagi pustakawan terdiri dari empat aspek yaitu aspek spesialisasi, aspek kepribadian, aspek perbedaan dan aspek terlihat, empat aspek ini harus dikuasai oleh seorang pustakawan karena ini merupakan aspek utama dalam membentuk personal branding. Kemudian empat aspek pendukung yang juga harus dikuasai oleh pustakawan dalam membentu personal branding yaitu aspek kepemimpinnan, aspek kesatuan, aspek, keteguhan dan aspek nama baik.

Semua informan peneliti menyimpulkan bahwa kelima informan berusaha membentuk personal branding mereka berdasarkan kemampuan spesialisasi mereka, pelayanan yang baik ramah yang mereka berikan kepada pemustaka, kepribadian dan tingkah laku yang baik dan selalu membantu pemustaka yang membutuhkan informasi yang mereka butuhkan, dan berdasarkan teori pedoman pembentukan personal branding dapat diketahui bahwa hanya informan Tony Hartanto yang menerapkan delapan aspek dalam pedoman pembentukan personal branding tersebut sedangkan keempat informan menerapkan 7 aspek yaitu spesialisasi, kepemimpinan, kepribadian, terlihat, kesatuan, keteguhan dan nama baik, aspek yang tidak ada dalam keempat informan yaitu perbedaan.

\section{DAFTAR PUSTAKA}

Aji, A. (2018). Analisis Personal Branding Pada Program Talkshow Santai Sore AniesSandi Di Situs Yotube.com. UIN Syarief Hidayatullah Jakarta. Retrieved from repository.uinjkt.ac.id

Florenza, E. (2019). Makna Simbolik Tari Kejai Pada Suku Rejang Di Kabupaten Lebong. Universitas Bengkulu.

Handayani, R. (2015). Personal Branding Pustakawan. Pustakaloka, vol.7(Insitut Agama Islam Negeri Ponorogo), 101-110. Retrieved fromjurnal.iainponorogo.ac.id

Inami, D. F. L., \& Nurislaminingsih, R. (2017). Analisis Bentuk Personal Branding Pustakawan Melalui Media Sosial (Studi Kasus Pada Akun Media Sosial Pustakawan di Kota SemarangSalatiga, dan Yogyakarta. E-Journal Undip, vol 6, No.4(Universitas Diponegoro),1-15.

Lorenza, C. (2019). Konsep Diri Kpopers EXO Di Kota Bengkulu (Study Kasus Komunitas EXO-L Di Kota Bengkulu). Kota Bengkulu: Universitas Bengkulu.

Marsela. (2019). Fenomena Penggunaan Instagram Dikalangan Androgini Kota Bengkulu. Kota Bengkulu: Universitas Bengkulu.

Murniaty. (2016). Upaya Membangun Citra Diri Melalui Pembentukan Personal Branding Pustakawan, (Universitas Sumatera Utara), 14. Retrieved from http://repositori.usu.ac.id

Sarnawai, M. D. (2012). Implementasi Pendidikan Karakter dalam Pembelajaran Sains di Sekolah Dasar Universitas Pendidikan Indonesia. Universitas Pendidikan Indonesia. Retrieved from repository.upi.edu

Sudarsono, B. (2006). Antologi Kepustakawan Indonesia (1st ed.). Jakarta: Sagung Seto.

Sugiyono. (2010). Metode Penelitian Kuantitatif, Kualitatif, dan R\&D. Bandung: Alfabeta. 
Palimpsest: Journal of Information and Library Science Vol. 11, Issue 2, 2020, page 68-124

Winoto, H. Y. (2016). Peranan Brand Endorser dan Personal Branding Pustakawan Dalam Membangun Citra Perpustakaan Dalam Tinjauan Komunikasi. Visi Pustaka, vol.18 No.2 Universitas Padjadjaran), 107-116.

Retrievedfromhttp://ejornal.perpusnas.go.id/vp/article/view/97/pd

f 